\title{
t......
}

\author{
「超高速大容量光通信技術」解説小特集号によせて \\ 中沢 正隆 \\ NTT 未来ねっと研究所（†239-0847 神奈川県横須賀市光の丘 1-1）
}

\section{Preface for Topical Papers on Ultrahigh Speed and Ultrahigh Capacity Optical Communication Technologies}

\author{
Masataka NAKAZAWA \\ NTT Network Innovation Laboratories, 1-1 Hikarinooka, Yokosuka, Kanagawa 239-0847
}

(Received January 18, 1999)

今日の情報通信の発展は目覚ましく,2000年には世界中 で2億台のコンピュータが互いに接続され, 音声, デー夕,テ キスト,画像など多彩な情報の交換を行うと予測されてい る。また国内をみると, 携帯電話も今や 4000 万人が使用し ており，固定電話の半分以上にまで急速に伸びてきてい る. 近い将来, 家庭の中で世界中のだれとでも高精細な画 像を伴う通信の時代がやってくるであろう.

今のところ家庭で使える情報量は概ね100kbit/sであるが, 動きの良い画像デー夕などを送る場合には $1 \mathrm{Mbit} / \mathrm{s}$ 以上が 必要である。それらが束になって構成される基幹網では テラビット級の高速大容量光通信が不可欠である。そし てその太束のネットワークがやがてライフライン的な役 割を果たすようになってくると思われる。

光通信の最初のフィーバーは1980年代の光ファイバの 低損失化・長波長半導体レーザー光源の開発であり,世界 中が損失の少ないファイバや長波長レーザーの作製につ いて競争した．第2のフィーバーは1990年頃からの小型エ ルビウム光ファイバ増幅器 (EDFA) 出現であり, 高利得 · 広帯域なEDFAを皆で作り上げた。今日のように光時間多 重(OTDM) や波長多重(WDM)のシステム技術が急速に発 展したのはこのEDFAの開発に負うところが大きい。そし て,この発展が光ネットワークの高機能化を加速してい る.

例えば, 各家庭での通信には異なった波長を割り当てる ことにより,ルーティングに便利なWDMが盛んに研究さ れているし,また全国の基幹網のネットワーキングにも波 長の違いを旨く使うことも出来る．その一方で高速信号 を一括して多重化できる超高速OTDM伝送は電子回路の 動作限界を超えた伝送速度で通信できる特徴を持ってい る。本解説小特集号では,これらTDMおよびWDMに関す る最先端技術についてそれぞれの専門の方々に解説して
いただいている。またそれらを支える超高速電子回路技 術, 超短パルス発生技術, 光デバイス技術についても合わ せて解説していただくことにより,超高速大容量通信技術 の全体像を浮かび上がらせたい.

光の将来技術に向けては次のようなことも言えよう. EDFAは低損失ファイバがなくとも長距離通信が出来るこ とを実証したので, 低損失なフッ化物ファイバやシリカ ファイバなどの研究は下火になった。また,コヒーレント 通信もEDFAをプリアンプとして用いたIM/DDと受光感度 にあまり差がないこと, EDFAの自然放出光とコヒーレン トな信号光の非線形相互作用により信号光の位相が乱さ れることなど, その本格的な開発は後回しになっている. しかし, 将来の様々な光通信の形態を考えると, 光をマイ クロ波のように使いこなすことが重要である。この意味 でやがて光の位相を駆使した光通信がフィーバーする時 代がやってくるように思うのである. EDFAから出る自然 放出光の除去も重要であり,ソリトン制御技術などは線形 と非線形の差を利用した雑音制御の良い一例であろう. この新しい伝送技術はやがて光の3R (Retiming, Reshaping, Regeneration)につながっていく重要な技術である。また, テラヘルツの周波数を用いた新しい周波数領域での通信 の研究開発も見逃せない. 我々が使っていなかった領域 には想像を超える興味深い現象やその応用技術が潜んで いるかもしれない.

この解説特集号では超高速大容量光通信技術の最近の 展開について解説していただいているが, 今の研究の延長 線上あるいはそのまわりにどんな新しい技術があるのか, また将来の通信のためにどのような研究をすべきなのか を自ら考えていただきたい. 光のスイッチングなど光非 線形を利用した光信号処理技術, 光等化技術, 超高速光 . 電子(マイクロ波) 融合技術などは興味深いように思う。 